\title{
Evaluation of the dietary patterns of individuals with type 1 diabetes who use carbohydrate counting at a public health unit in Brasília-DF
}

\author{
Denise Glória Silva de Paula da Costa*, Maria Aparecida Barbosa Nascimento \\ From 20th Brazilian Diabetes Society Congress \\ Porto Alegre, Brazil. 11-18 November 2015
}

\section{Objectives}

To evaluate the eating behavior of individuals with type 1 diabetes (T1D) and the risk of developing chronic complications.

\section{Materials and methods}

An analytical cross-sectional study with a convenience sample consisted of 23 individuals with type 1 diabetes, who needed Intensive insulin therapy and were treated at a public health unit in which carbohydrate counting was used in the treatment. Through interviews, information on socioeconomic data and feeding behavior was obtained. Anthropometric measurements (weight, height and waist circumference) were also taken.

\section{Results}

It was found that most individuals of the sample correctly applied the carbohydrates counting method. For the majority of the sample, food intake was found adequate when compared with that recommended by the Dietary Guidelines for Brazilian population (Guia Alimentar para a População Brasileira), in regard to the groups of carbohydrates, vegetables, proteins of animal and vegetable origin, oils and fats. Most of the sample had a daily or a 2 to 4 times a week intake of whole foods. In contrast, consumption of dairy products and fruits was insufficient among most participants. It was found that $39 \%$ of the sample had some degree of overweight, as measured by the body mass index, and $43.4 \%$ of the sample had a waist circumference higher than the recommended value.

\section{Conclusion}

Helping individuals with T1D is essential in maintaining an appropriate body weight and in preventing abdominal obesity. This should be coupled with a balanced diet, which is essential in the treatment in order to minimize long-term complications and aids achieving good glycemic control. It is crucial to offer periodic training to ensure correct application of the carbohydrate counting method.

Published: 11 November 2015

doi:10.1186/1758-5996-7-S1-A109

Cite this article as: de Paula da Costa and Nascimento: Evaluation of the dietary patterns of individuals with type 1 diabetes who use carbohydrate counting at a public health unit in Brasília-DF. Diabetology \& Metabolic Syndrome 2015 7(Suppl 1):A109.

Submit your next manuscript to BioMed Central and take full advantage of:

- Convenient online submission

- Thorough peer review

- No space constraints or color figure charges

- Immediate publication on acceptance

- Inclusion in PubMed, CAS, Scopus and Google Scholar

- Research which is freely available for redistribution 